\title{
Post-Foucauldian Discourse and Dispositif Analysis in the Post-Socialist Field of Research: Methodological Remarks
}

\author{
Magdalena Nowicka-Franczak \\ University of Lodz, Poland
}

DOI: http://dx.doi.org/10.18778/1733-8077.17.1.6

\section{Keywords:}

Discourse Analysis;

Dispositif Analysis;

Michel Foucault;

Neoliberalism; Post-

Socialism; Central and

Eastern Europe

\begin{abstract}
Post-Foucauldian discourse and dispositif analysis, a methodological approach inspired by the work of Michel Foucault and developed in Western Europe, over the last decade has gained an increasing amount of attention from Eastern European researchers. Yet, this interest has not been accompanied by sufficient reflection on the post-Foucauldian perspective's adequacy for studying power, governance, and subjectification in post-socialist societies. In particular, there is little criticism that would take into account the current discussion on Foucault's ambivalent attitude towards neoliberalism. The goal of this article is to examine this line of criticism of Foucault's late works and to point to its importance for dispositif analysis carried out in Eastern and Central European societies (e.g., Poland) in comparison to analyses carried out in Western Europe (e.g., Germany). I propose a number of methodological recommendations that aim at adapting post-Foucauldian research instruments to facilitate analyzing power relations in the post-socialist context; these include: an interdisciplinary combination of discourse analysis and an analysis of macroeconomic and macrosocial factors; an analysis of the practices of normalization in post-socialist societies with reference to the Center-Periphery relationship; introducing elements of semiology, anthropology of the contemporary and cultural identity analysis to dispositif analysis.
\end{abstract}

Magdalena Nowicka-Franczak is an Assistant Professor at the Department of Research on Social Communication, University of Lodz. Her academic interests focus on the public debate in Central and Eastern Europe, the collective memory of Shoah and WWII, post-Foucauldian discourse analysis, and postcolonial studies. Her book, ti- tled Niechciana debata. Spór o ksią̇ki Jana Tomasza Grossa [An Unwanted Debate: The Dispute over Jan Tomasz Gross's Books] (2017), won Stanisław Ossowski Prize of the Polish Sociological Association.

email address: m.nowicka_franczak@uni.lodz.pl 
A conversation with Zygmunt Skórzyński, who quoted an opinion of a French sociologist: in America, they have very well-developed research tools, but no problems as such. And they produce second-rate ideas. In the USSR, they have real and complex problems, but no research tools. In Poland, there are both real problems and an elaborate set of research tools.

Aren't there? I was delighted with this opinion of a foreign scholar. [Zawieyski 2011:601 (trans. MNF)]

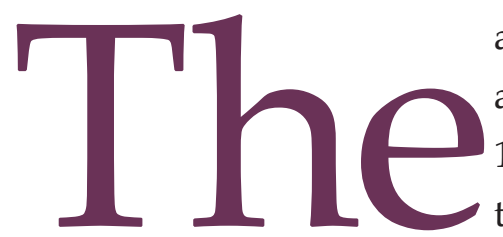

anecdote opening this article dates back to 1958 and comes from the diaries of Jerzy Zawieyski, a Polish intellectual and writer. He quotes, after Zygmunt Skórzyński, a sociologist and activist of the Catholic intelligentsia, the praise of Polish sociologists' research tools, which was supposedly made by a scholar from France, from the West. According to Remigiusz Ryziński (2017:165), that foreign scholar was Michel Foucault, who between 1958 and 1959 stayed in Warsaw as the head of the Center for French Culture at the University of Warsaw and with whom Skórzyński, as a member of Warsaw's Crooked Wheel Club (Klub Krzywego Koła, a club of the Catholic intelligentsia), might well have spoken. The text devoted to the history of madness in Western social discourses that Foucault (2006) was then working on could be treated as a sociological study rather than a purely philosophical or historical work; one should not then be surprised by the fact that Foucault was labeled as "a sociologist."

There are, however, so few testimonies of Foucault's stay in Warsaw that it is by no means certain that the above-mentioned opinion was expressed by him. Yet, today without Foucault the anecdote loses all its charm. The essence of this story is the fact that a legendary thinker (who, of course, was not yet legendary in 1958), praised Polish social sciences while criticizing American and Soviet research. Coming from the civilizational center of Europe, he boosted the self-esteem of the peripheries not only by comparing its accomplishments to those of the Western countries, but also to those of the USSR, on which Poland was at that time politically and economically dependent, also in the area of social research. For Polish sociologists and humanists, deprived of access to many international channels of scientific communication by the communist regime, words such as those attributed to Foucault expressed a strong desire for appreciation from those who, while setting the tone in global science, were usually blind to what scholars from Eastern Europe had to offer. The long-term dependency on the USSR, which might be compared to a colonial relationship, especially in terms of political dominance (Moore 2001), shaped the perception of Poland as the Periphery of Europe, jammed between two Centers: the Western (praised by the majority of Polish society) and the Eastern one (which put a direct imprint on the every-day reality) (Bielska and Wróblewski 2017) and resulted in an inferiority complex among Polish intelligentsia with regard to their civilizational position defined against that of Western European intellectual elites which served as a reference point (Zarycki 2014).

In post-socialist Europe, this inferiority complex has not disappeared. For scholars from Eastern and Central Europe, what was at stake within the peripheral field of social sciences was not so much being recognized in the West as a distinct research "subculture," but being included in the academic world despite representing Europe's peripheries (Warczok and Zarycki 2014; 2016). What often served as a means to this end was uncritical copying of theoretical and methodological frames borrowed from the Center, 
without taking into account the specificity of the local context of empirical research. With this in mind, in this article, I discuss the methodological aspect of the post-Foucauldian perspective.

The post-Foucauldian approach to discourse, power, and the subject is a heterogenic and multi- and interdisciplinary way of studying the relationship between knowledge, the discursive and ideological aspects of social communication, and the practices of governing society. The key terms in this approach (e.g., discourse, dispositif, knowledge, power, governance) are mostly defined based on Foucault's texts. Yet, his works are not the only point of reference. This is, for instance, conspicuous in empirical studies where post-Foucauldian researchers take inspiration from other sources (e.g., sociology of knowledge, critical linguistics, or symbolic interactionism). The post-Foucauldian approach comprises, inter alia, discourse analysis within the framework of governmentality studies (Angermüller and Van Dyk 2010), dispositif analysis (Jäger 2001; Bührmann 2005; Bührmann and Schneider 2008; Raffnsøe, Gudmand-Høyer, and Thaning 2016), sociology of knowledge approach to discourse (Keller 2011; Bosančić and Keller 2016), and subjectivation analysis (Keller, Schneider, and Viehöver 2012; Bosančić 2018; Bosančić, Pfahl, and Traue 2019). Post-Foucauldian methodologies share the concept of multiplied power actualizing itself in social practices, including the production of knowledge and theoretical discourses (Diaz-Bone et al. 2007). Discourse, as an object of analysis, is understood here as a set of enunciations (with their material grounding), the production of which is "[in every society] at once controlled, selected, organized and redistributed by a certain number of procedures" (Foucault 1981:52). In empirical research, discourse refers to the production of meaning which turns any form of discursive prac- tice into a strategic tool of the actualization of the order of knowledge.

Developed since the late $20^{\text {th }}$-century in the West, Post-Foucauldian methods have recently been gaining more and more attention from scholars from Eastern Europe, including Poland. This interest has not been accompanied, however, by sufficient reflection on the theoretical and methodological adequacy of the post-Foucauldian perspective for studying power, governance, and subjectification in post-socialist societies. This is closely connected with the critique of the neoliberal bias in Foucault's late thought. For many of his admirers, Foucault was a thinker who went far beyond the Kantian and Nietzschean critique of Western culture and was often a step ahead of his contemporaries. However, in the field of contemporary Foucauldian studies, this label of a postmodern, anti-Hegelian prophet with an anarchist message seems to no longer fit snugly. "Michel Foucault was a far-sighted theorist, but also a creature of his time," Samuel Moyn points out (as cited in Zamora and Behrent 2016:I). To put it more precisely, Foucault was primarily a creature of a given geopolitical space and of a particular form of rationality in which he articulated his concepts.

In the first part of the article, I discuss Foucault's alleged endorsement of neoliberalism and, in particular, its impact on dispositif analysis. In the second part, I investigate the specificity of the post-Foucauldian research carried out in the Central and Eastern European context (i.e., Poland) in comparison to analyses performed in Western liberal democracies with developed capitalism (i.e., Germany). To illustrate my arguments, I will focus on educational discourses and practices because of their significance for the subjectification of individuals. In the closing remarks, I propose several research guidelines for 
dispositif analysis conducted in Poland, where this methodological perspective has been systematically gaining visibility among social scientists. The aim of these postulates is to confront post-Foucauldian conceptual devices with the local specificity of analyzed discourses and social practices.

\section{Foucault: A Creature of His Place and Time}

What is usually highlighted in Michel Foucault's intellectual biographies is his professional duality. While critics willingly point out his misguided actions and statements as a public intellectual and an activist, his academic and theoretical preoccupations are regarded as relatively impregnated against the impact of his politics and views embedded in a certain social context (Eribon 1991; Macey 1993; Sarasin 2005; Fisch 2011; an exception is the biography by Miller 1993). The consequence of such a representation of Foucault is the fact that he is regarded, according to Daniel Zamora (2014), as "an untouchable figure within part of the radical left," and the general tendency to draw "the far too consensual image of Foucault as being in total opposition to neoliberalism at the end of his life."

Even Paul Veyne, in his text Foucault: His Thought, His Character published as late as 2008 in French and two years later in English, rejects the tendency to reduce Foucault to being "the product of a certain line of '1968 thinking'"' (Veyne 2010:1). He points, however, to the fact that the discourse formulated by Foucault was a result of discursive practices marked by a specific episteme and set-ups regulating its production. Escaping the limitations of one's thinking is possible through inventing a new discourse that may not replicate the limitations of an old one, but still has boundaries delineated by the historical a priori. In other words, thinking is not ideological by itself, but it is defined by a discourse that determines one's perception of reality (Veyne 2010:13, 2729 ). By consistently calling Foucault a skeptic and “a good positivist," Veyne (2010:108, 118) suggests that the particular and material circumstances of the production of theoretical discourse put their stamp on Foucault's work, which he must have been aware of, rejecting philosophy's claim of discovering a universal truth and transcendental values, and, in effect, refusing to address in his research the social aspects of contemporary capitalism and consumerism.

Stuart Elden (2016a) points to this problem explicitly, claiming that in the studies of Foucault's thought, his "political activism and engagement with contemporary problems [are] underappreciated." However, he highlights that "[q]uite how he combined that activism with the academic work is difficult to grasp" (Elden 2016a), since Foucault's work was always based on archival research, which made his conceptions and terms historically and geographically specific. Adding to that the question of public activity, which is difficult to fully separate from academic work, one cannot ignore the problem of using Foucault's perspective for analyzing other historical periods or political and cultural spaces. According to Elden (2016a), taking into account the discrepancies between the analyzed portion of social reality and Foucault's writings "would be truer to his spirit than uncritical applications." ${ }^{11}$

\footnotetext{
${ }^{1}$ Such a critique of Foucault has been looming over the post-Foucauldian approach to discourse and power since its early days. Since the late 1980s, post-Marxist subaltern studies have argued that the Foucauldian model of power/knowledge and discourse should not constitute one of the main inspirations for postcolonial theory, but turn into an object of deconstruction as a pure derivative from the Western European tradition of critical reasoning and subject positioning (e.g., Spivak 1988; Ahmad 1992; Nichols 2010).
} 


\section{Foucault's Evaluation of Neoliberalism}

Already in his 1993 controversial biography of Foucault, James Miller (1993:310) notes with regard to the lectures delivered at the Collège de France in early 1979 that the thinker "turned his own attention to modern liberalism, analyzing its character with unprecedented sympathy." Today, his ambivalent attitude towards the post-1968 Left in France, his harsh criticism of the welfare state and social security, his sympathy for the negative income tax proposed by Milton Friedman and by Lionel Stoléru in France, and the ambiguities in his evaluation of neoliberalism, found mostly in the abovementioned cycle of lectures published in 2008 as The Birth of Biopolitics, are debated as major shortcomings of his thought. In The Birth of Biopolitics, he elaborated on the concept of governmentality, the rationality of governing people through managing their freedom in the framework of political economics and thanks to a strategic operating device, the dispositif of security, which functions as a tool of the selection of meaning which is socially legitimate, utile, and presented as the truth (Foucault 2008; see also Lemke 2001).

The question of Foucault's attitude towards neoliberalism was raised many times after his death (e.g., Larner 2000; Behrent 2009), but the debate has become heated only in the last decade. In 2012, a conversation took place between François Ewald and Gary Becker, in which they both, although starting from different standpoints (and Becker admitting to not having "read much of Foucault"), came to the conclusion that Foucault had offered an "apology of neoliberalism" concerning its non-disciplinary, subjectificating logic of governing people (Becker, Ewald, and Harcourt 2012). In the same year, Geoffroy de Lagasnerie, in La dernière leçon de Michel Foucault [The Last Lesson of Michel Foucault] (2012), argues that Foucault proposed not a dogmatic but an experimental interpretation of (neo)liberalism, rooted in the critique of sovereign and disciplinary power, and in the perspective of the microphysics of power. Seen from this angle, neoliberalism is a "tool of the critique of reality and theoretical thought," "a kind of experimental dispositive," an invitation to rethink the relationship between the state, the market, and individual freedom through a rejection of the language of the state in favor of the concept of economic rationality, and, most of all, "a purely intellectual construct" formulated as a refreshing theoretical proposition for the Western Left (Lagasnerie 2012:29, 148, 174-175 [trans. $\mathrm{MNF}]$ ). Lagasnerie's point of departure is a diagnosis of the futility of the contemporary critique of neoliberalism, which, in his opinion, revolves around the same arguments and clichéd ways of understanding neoliberalism. They are opposed by Foucault, who sees neoliberalism not so much as an ideology of the dominant class, but a non-totalizing art of governing individuals, which takes into account their diversity and gives them a margin of independence from the rationality of government. Neoliberal governmentality moves away from a disciplinary regulation of people's conduct, and towards their nondirective optimization or even de-subjectification (Lagasnerie 2012:12, 35, 57, 155, 175).

A further step is taken by critics who see Foucault's work as incorporating neoliberalism into the theoretical discourse. What serves as a highly debated example of such a "deconstruction" of late Foucault is the volume Foucault and Neoliberalism, edited by Zamora and Behrent, published in 2014 in French and 2016 in English. Foucault is charged there with misreading the productivity of economic liberalism, having an indefensible faith in the emancipatory dimension of neoliberal power, and focusing on identity struggles and on groups excluded from the neo- 
liberal forms of employment or, in general, from the governmental mode of subject-making (such as the mentally ill or prisoners), instead of standing up for the economically exploited majority. He is accused of justifying the shift in the left-liberal policy away from the struggle against social inequalities as such, towards the limited counteracting poverty as a final result of structural inequalities. In consequence, he is labeled as an anti-statist, an enemy of economic interventionism and social security. As Behrent (2016:185) claims,

the tragedy of Foucault thought is that the conceptual tools he had so skillfully deployed to shine a withering critical light on postwar society proved distinctly less trenchant when directed at the emerging neoliberal order-the contours of which, at the moment of his untimely death in 1984, Foucault could only have glimpsed in the vaguest of terms.

In this context, Mitchell Dean (2018:43) offers a more neutral view of Foucault's attitude towards neoliberalism. Firstly, for Foucault, neoliberalism meant "not simply a philosophy of freedom and the market," but a practical form of "governing states and other organizations" and finally individuals. Secondly, neoliberal governance was favored by him as a post-disciplinary system

in which the field is left open to fluctuating processes, in which minority individuals and practices are tolerated, in which action is brought to bear on the rules of the game rather than on the players, and finally in which there is an environmental type of intervention instead of the internal subjugation of individuals. [Foucault 2008:259-260]

In other words, neoliberal governmentality is about governing people, but with a considerable margin of freedom in comparison to former modes of governing the people. Thirdly, at that time, Foucault was one of the first scholars who not only politicized neoliberalism as a set of strategic practices of governance, but saw it as critically problematizing the social order of his times, rather than being a supra-structural economic project. Fourthly, his analysis of neoliberal subjectivity focuses on ordoliberalism and early American neoliberalism with human capital theory, and not on neoliberalism in all its breadth. Therefore, the argument that he misreads general neoliberal practices of subject-making seems misleading as Foucault's analysis is limited to a few features of the phenomenon. As Dean (2018:50) warns,

When we use Foucault today we can no longer imagine, however, that we have entered a position of safety or that his name invokes an intellectual insurance policy against analytical missteps and naïve political enthusiasms. We should also be aware that there is a struggle going on over Foucault's legacy, including by those who would give us a Foucault consistent with economic or political liberalism.

Sharing some of these reservations, I believe that, in many instances, the ideas of the author of The Birth of Biopolitics and of his critics simply do not overlap. Firstly, the subject and aim of Foucault's thought tend to be wrongly identified. It is not making neoliberalism the "subject of sociological theory" or seeing it, in a Marxist vein, as a late phase of capitalism or, in a liberal spirit, a political doctrine (Laval 2018:19, 28, 36, 71). Foucault's goal is a non-economic analysis of a historically defined shift in the way and rationality of governing people as economic subjects; a move away from regulation towards normalization and beyond.

Secondly, the weakness of the criticism in question is its presentism (Specter 2015:368). For example, this 
is how Dean and Zamora (2018) conclude their critical review of Les aveux de la chair [Confessions of the Flesh], the fourth, unfinished part of The History of Sexuality, which is read today as an implementation of the project of neoliberal optimizing individual conduct in order to rethink the liberational aspects of the technologies of the self, inherited from ancient ethics and radically transformed by Christianity:

From Trump to Brexit, to the demise of French socialism, the recent disaster of the Italian elections, and the crisis at the Nordic heart of the social democratic model, the folly of this strategic intersection and its evacuation of the problem of economic exploitation and inequality has become all too plain to see.

Despite the accuracy of the remark suggesting that Foucault had not foreseen the alarming direction of the development of neoliberalism and its practices, which have not only not banished the oppressive institutions of the state and market, but have also led to increased inequalities in capitalist economies, this criticism clearly reveals its own ahistorical nature. Foucault's texts on German ordoliberalism, the Chicago school of economics, the program of Giscard d'Estaing's government, and works by Raymond Barre are juxtaposed with the governments of Margaret Thatcher and Ronald Reagan, the Washington Consensus, or the economic crises of the early $21^{\text {st }}$ century. Out of such a battle, Foucault, who died in 1984, cannot come unscathed, even though he never declared that he wanted to study neoliberalism in its Realpolitik version. On the contrary, he highlighted the temporal, spatial, and situational limitation of his analyses (e.g., Foucault 1991:380); he warned against the temptation to read history through a contemporary lens (1976:30-31); in his 1979 lectures, he stressed that the subject matter of his research were the kinds of relationships between the state and society which were "peculiar to a particular technology of government" (2008:319). Foucault was interested in the response of neoliberal intellectual discourse to the crisis of liberal governmentality after 1968; some scholars see a distant prediction of the contemporary problems of liberal democracies in his reflections on the replacement of the homo politicus by the homo oeconomicus (Brown 2015:72-80).

The third problem is the textual idealism imputed to Foucault by critics, who tend to use it themselves. Ascribing to him a belief in the ideological honesty of the manifestos of early neoliberalism that he quoted, contemporary commentators often insufficiently differentiate between what Foucault refers to and his own theses. The fact that he never explicitly rejected neoliberalism and stressed the relationship between emancipatory programs and government is misinterpreted as a lack of critical distance towards the subject of his study rather than as a politicization of the neoliberal project (Hansen 2015:297). Seeing Foucault as strongly antipathetic to the state is also misguided. The fact that he writes about "State-phobia" does not mean that he himself shares it (Foucault 2008:75-76). A particular object of his criticism is not the state as an idea, but its specific realization: a police state with a disciplinary power apparatus. He also points to the paradox that the ideas of limiting the state's powers usually contribute to their transformation or increase in other spheres of social life.

Fourthly, criticism of Foucault often works as a pars pro toto, at the expense of reflecting upon the whole of his work. Critics quote the same passages, reading them literally and treating them as a source of conclusive declarations. Allegedly, one of the "proofs" for Foucault's neoliberal inclinations is his 1984 statement (Foucault and Rabinow 1984): 
I think I have in fact been situated in most of the squares on the political checkerboard, one after another and sometimes simultaneously: as anarchist, leftist, ostentatious or disguised Marxist, nihilist, explicit or secret anti-Marxist, technocrat in the service of Gaullism, new liberal [French original: neoliberal], and so on. An American professor complained that a crypto-Marxist like me was invited to the USA, and I was denounced by the press in Eastern European countries for being an accomplice of the dissidents. None of these descriptions is important by itself; taken together, on the other hand, they mean something. And I must admit that I rather like what they mean. [383-384, emphasis added]

Foucault does not deny any of the labels attached to him, but he does not embrace any of them, either. One could see this as a practical realization of the postulate to make criticism a permanent research task. At the same time, one may see the attempts at pinpointing Foucault's political worldview as a manifestation of the power he himself wrote about, obligating the subject to confess the truth about themselves (Hansen 2015:292).

Finally, the abovementioned way of reading the lectures on governmentality, though intellectually provoking, seems excessively restricted by his critics' Marxist lens and by a tendency to treat "neoliberalism as the explanatory mechanism" of any pathological aspects of current social and economic life (Hansen 2015:292). As a result, an alleged neoliberal bias functions as an answer which Foucault formulated as a result of his anti-communism and in response to the crisis of the welfare state of his time. When viewed from a post-Marxist perspective, what Foucault actually tried to do seems unimaginable: namely, he attempted to find a potential for the critical art of government in certain forms of neoliberalism.

\section{Post-Foucauldian Methodology and Neoliberalism}

The critique of Foucault's theory of neoliberalism has consequences for the application of his method in empirical studies of (neo)liberal practices (e.g., Bröckling, Krasmann, and Lemke 2010; Diaz-Bone and Hartz 2017). In this context, the main objections towards the post-Foucauldian approach concern its ambiguous non-engagement in the critique of ideologies, and a tendency to reconstruct a complex social reality in a reductive manner and to make inferences about the process of subjectification and subjectivation only on the basis of discourse, as well as to reproduce fragments of neoliberal discourse in his analytics of power, which results in the appropriation of governmentality studies by the neoliberal system of the production of scientific discourse (Rehmann 2016). Moreover, what is highlighted as a weakness of the post-Foucauldian perspective is that it overlooks the emotional component of discourse and non-discursive practices, ignores biographic conditions that influence the productivity of power relations and neglects economic and class relationships on the global and local scale, and finally gives little attention to the diversification of democratic and neoliberal capitalist power in societies whose discourses and institutions are analyzed using this approach.

As a remedy, some researchers propose combining the post-Foucauldian approach with other qualitative methods, for example, the biographical method (Tuider 2007; Pfahl, Schürmann, and Traue 2015), the sociology of knowledge (Keller 2011), and intersectional discourse analysis (Paulus 2015) or quantitative methods, for example, correspondence analysis (Hamann et al. 2019). Nonetheless, the problem of Foucault's worldliness remains. By worldliness, 
I mean what Edward Said (1983) understood as a historical and material grounding of the author and their texts in the social world. In particular, the "worldly" character of Foucault's concepts concerns dispositif analysis. Present in his oeuvre from the mid-1970s, the term dispositif refers to a heterogenic composition of discursive and non-discursive elements of social reality interconnected with the relations of power (Foucault 1980:194-198). This apparatus responds to forms of power/knowledge emerging within the Western epistemes and heuristic models of government and governed subjects. Hence, the dispositif of security related to neoliberal governmentality is a problem-solving operator that functions in the framework of the discourse/knowledge order, which derives from the early neoliberal thought developed in French, German, and American intellectual milieus.

As a perspective to study relations between power, knowledge, the subject, and the truth, the dispositif approach focuses on "the processes of the reduction of meaning" (Angermüller 2010:90), caused by discursive and non-discursive practices, as well as by physical objects, which all serve together as a device of power exercised both on subjects and objects (Jäger 2001; Link 2006; Caborn 2007). As an analytical category, dispositif "is empirically identified due to a more or less systematic use of a certain methodology" (Bührmann and Schneider 2008:152 [trans. $\mathrm{MNF}]$ ), aimed at reconstructing in an abductive fashion the relations between orders of knowledge, orders of discourse, practices of subjectification, and its materializations and objectifications in social practices. For discourse researchers, dispositif usually serves as a framework to combine textual analysis with analysis of the practical and material context of discourse production and its impact on the subjects (Hoffarth 2013:98-99). Although dis- course analysis is almost always an essential part of dispositif analysis, it is not an occasional discourse, but a particular order of knowledge and the associated discursive and non-discursive practices that create subjects (Schneider 2015:28-29).

The first methodological dilemma stemming from the peculiarity of Foucault's perspective is connected to the question of whether its direct application of the study of diverse local contexts is justified. The second dilemma stems from Foucault's attitude towards neoliberalism (in its narrow sense). The analysis of the dispositif of security carried out within governmentality studies is connected with a critique of the current influence of neoliberal discourses and public policies on the subjectification of individuals. Meanwhile, what Foucault proposes in his lectures is a genealogy of the subject emerging from a historically and locally specific neoliberal elitist discourse. That is why, in order to use Foucault's perspective in studying the practices of contemporary neoliberalism, one should either reduce it to a retrospective inspiration or (which seems a more useful choice in terms of its epistemic value) subject it to an empirical test, which is perhaps a sine qua non of the (post)Foucauldian sociology of power (Jeanpierre 2006:105-106).

\section{Towards a Post-Socialist Dispositif of Security}

One of the fields that are affected by the theoretical and methodological difficulties present within dispositif analysis are the relations of power in Central and Eastern European post-socialist and peripheral states, ${ }^{2}$ where dispositif analysis is used as a meth-

\footnotetext{
${ }^{2}$ Relations of power in Central and Eastern European post-socialist states are not the only field of research where the application of (post)Foucauldian perspective should be preceded
} 
od for a radical reconstruction of power relations between the self, social structure, law, economy, the truth, and the state in the context of rapidly developing post-1989 capitalism and growing individualism in social life (e.g., Czyżewski 2012, Chutorański 2013a; 2013b; Ostrowicka 2015; Nowicka-Franczak 2017). Paraphrasing the question from the title of Laurent Jeanpierre's article-“'Une sociologie foucaldienne du néolibéralisme est-elle possible?" [Is Foucauldian Sociology of Neoliberalism Possible?] (2006) - we should pose another question: is Foucauldian or post-Foucauldian sociology of post-socialism possible? Are post-socialist governmentality and its dispositif of security possible, according to Foucault's work? And is dispositif analysis a relevant method for post-socialist research?

The first reservation stems from Foucault's minor academic interest in Eastern Europe, despite his public engagement in political support and humanitarian aid offered to dissident circles. In Eastern Europe, and especially in Poland, where Foucault lived between 1958 and 1959 and where he finished writing History of Madness, as he put it ironically, "in the stubborn, bright sun of Polish liberty" (Foucault 2006:XXXV), he is praised for his consistent critique of Stalinism, as well as for his "ferocious hatred of everything that evokes communism, directly or indirectly" (Eribon 1991:194). His Discipline and Punish was frequently read by Eastern European readers as an allegory of totalitarian regimes. What makes Foucault so attractive for Eastern European scholars is his image of a Western leftist thinker without a communist bias. However, his attempts at making a link between Western and Soviet mod-

with the initial reconsideration of theoretical and methodological tools and the testing of their empirical adequacy. Another such field is, for instance, Latin American studies where the Foucauldian approach is widely disseminated or the studies of the Global South. ernization and subjectification practices are rather superficial. In his work on discipline, Foucault made only a vague comparison between Western modernization and the Gulag. In his 1975-76 lectures at the Collège de France, Society Must Be Defended, Foucault (2003:260-263) denounced the discourse of class struggle as racist not only in its Soviet extreme version, but also as a tool of any socialist form of power. According to him, the Soviet Union and communist Eastern Europe functioned as police states governed by an administrative force within the logic of socialism - though not in a Western governmental way, but rather in its excess (see, e.g., Foucault 2001a:36; 2001b:64-65; 2001c:401; 2001d:1158).

His late writings include many remarks on socialism, but mostly restricted to comments on its French or German variants. In his 1979 lectures, he rejected the concept of the "autonomous governmentality of socialism," claiming that "there is no governmental rationality of socialism," no "governmental reason" (Foucault 2008:92-93), as socialism functions solely within an economic, historical, and administrative rationality, but does not produce means of "conducting the conduct" of individuals, certain categories of people, and whole populations. Foucault refers to the Marxist origins of socialism, but he does not consider the Leninist reading of Marx's work in terms of revolutionary rationality or their practical realization in Eastern Europe (indeed, he barely mentions East Germany). What interests Foucault in the context of socialism is the possibility of applying some of its elements to neoliberal rationality; this strategy, however, cannot be a symmetrical synthesis of both types of governance (he discusses this using the example of the transformations in postwar social democracy in West Germany [Foucault 2008:8891]). For him, "socialism can only be implemented connected to diverse types of governmentality. It 
has been connected to liberal governmentality and then socialism and its forms of rationality function as counterweights, as a corrective, and a palliative to internal dangers" (Foucault 2008:92). The only remark which refers to the Europe of his time as a whole concerns socialism's attempts at constituting some form of collective economic sovereignty instead of the one superseded by market liberalism (Foucault 2008:283).

In his interviews, Foucault differentiates between Soviet totalitarianism and Eastern European socialism. For example, he points to the strong psychological and cultural relationship between the societies of France and the then Polish People's Republic (Foucault 2001e:804) and to the exceptional role played in Poland by the Church as a mediator between the communist party and the working class, in which he actually sees the tragic ridiculousness of Polish socialism (Foucault 2001f:1088). His remarks on the region do not go beyond journalistic commentary, perpetuating the motif of the oppressive Soviet Big Brother and the dissidents fighting against the regime. Foucault intended to give lectures on the governmentality of totalitarian parties and in autumn 1984, to conduct a seminar on the possibility of a socialist governmental reason which could have been invented rather than deduced from socialist thought, but he did not manage to carry out this plan (Elden 2016b:109-111, 201, 206).

Regardless of the conclusions on socialist governmentality which Foucault could have offered, what interests the researchers in Central and Eastern Europe today is the post-socialist reality: democratic and capitalist, but produced out of the ruins of socialist political economy, having its source in Soviet Marxism and Leninism. I do not use the phrase "out of the ruins" metaphorically but literally, since the economic and financial inefficiency of the socialist system was the most important factor determining the transformation of the system in the region, along with social mobilization and a favorable international situation. The long-term aim of the transformation was to narrow the civilizational gap between Eastern and Western Europe, measured by individual material and civil aspirations (Gomułka 2016:19; see also Kovacs 1992).

In contrast, Foucault focused on the laboratories of the art of government, on isolated cases of relatively coherent dispositifs of power, supported by a consistent political economy. The situation of post-socialist countries does not easily yield to such classifications. Below, I concentrate on the case of Poland. On the one hand, this country is offered as an example of an effective system transformation from authoritarianism and socialism to democracy and capitalism, leading to economic success in macroeconomic categories (Gomułka 2016:20). On the other hand, the state of liberal democracy in Poland is fragile, especially with regard to civil rights. A prominent place within the public discourse and the symbolic sphere is invariably occupied by nationalist and xenophobic ideas, as well as those characteristics of premodern Christianity (Porter-Szücs 2014). One could speak of Polish material and economic modernization without axiological modernism (Sowa 2015:27f) conditioning the liberal "government through freedom."

The first reforms allowing market business activities in selected industries were introduced in Poland before the transformation (e.g., Wilczek's law of 1988-named after the industry minister at the time, Mieczysław Wilczek). To some extent, the economic transformation preceded the political one, but it gathered pace and was discursively legitimized 
only in the critical year of 1989. The strongly imitative character of capitalist discourse, given authority by the Western counselors to the first democratic governments (e.g., Jeffrey Sachs and George Soros), did not and could not (because of the historical and material context) go hand in hand with a similar repertoire of practices and technologies of the self to those described by Foucault in Western contexts. As a result, the imitation has not led to direct copying of the West, but to a hybridization of the forms of governance we see nowadays, for example, to the discord between the discourse of success and the historical necessity of the neoliberal transformation, on the one hand (Kubala 2019:129-145), and the social memory of the period of transformation, on the other (Laczó and Wawrzyniak 2017).

The change towards capitalism, justified by Western European neoliberal discourse of the second half of the $20^{\text {th }}$ century, took place in Poland within a very short period, but did not entail a full formation of neoliberal rationality of government that would be close to the one diagnosed by Foucault, an instrument of which would be a "classic" dispositif of security. One of the tasks of the dispositif of security is minimizing the risk connected to the possible incompatibility of individuals with the rules of the market game-both by normalizing their life aspirations and by affirming individual resourcefulness, which is supposed to guarantee, usually deferred, economic security, as well as by taking care of those who are permanently or temporarily "unresourceful" so that society would not incur losses as a result of their presence (Foucault 2007:11; 2008:65-66).

Comparing Western neoliberal governmentality and post-transformational practices of government, Mikołaj Lewicki (2018:388 [trans. MNF]) states that, "[i]n Poland, it would be difficult to say that organized modernity in its radical form was implanting the rules of delayed gratification and security for one's activity (resourcefulness)." On the contrary, the new capitalist social order reinforced a sense of risk and the unpredictability of the social and material situation, normalizing the understanding of the changing conditions as a necessary leap from pre-modernity towards modernity, which was bound to entail some casualties. As a result, in many respects, Poland was in the vanguard of neoliberal changes introduced without sufficient provisions being made for employees, which may be exemplified by the privatization of many sectors of the country's economy, promoted in the post-transformation discourse and deregulation of economic life, leading to a serious weakening of the nation-state's power over the flow of capital (Lewicki 2018:406-407).

The post-transformation model of subjectivity promoted in the media and public policy is based only to a small extent on the values of egalitarianism, social solidarity, and liberty understood as free and uncompromising self-expression. It is replaced by liberty directed towards new rationality, which expresses itself in realizing one's professional and consumerist aspirations within the market game (Kubala 2019:292-301). As a result, in many cases, as Anda Rottenberg, a Polish art critic and curator, puts it, "[i]n Poland, the people who profit from freedom the least are those who have fought for it" (as cited in Hugo-Bader 2016:19 [trans. MNF]).

Calling post-transformation Poland a leader of neoliberal governmentality is, however, a serious oversimplification. Despite the fact that consecutive governments of democratic Poland, regardless of their ideological affiliation, have been using a (neo) liberal economic discourse and juggling promises of increased welfare and of improving the quality 
of public services, as their basic political strategy. Such a strategy is also popular in Western liberal democracies, but what is noteworthy in the case of Poland is the justification that is typically provided for the promised solutions. They are supposed to result in narrowing the "civilizational gap" between post-socialist and Western countries and restore the citizens' dignity (Ziółkowski 2015:159-161). On the one hand, these claims are formulated in opposition to neoliberal capitalism and highlight its negative effects on the individual, such as precarization, growing social stratification, and pressure to subordinate the educational and developmental path to the needs of the labor market (N.B.: these are effects unforeseen by Foucault). Dignity claims are sometimes embedded within a retro-utopian discourse, built upon, inter alia, a nostalgia for socialism (Mikołajewska-Zając and Wawrzyniak 2016), anti-Western slogans (prophesying the moral demise of the West, which "worships" consumerism and cultural liberalism), and a shift back towards the authoritarian rationality of government (Gdula 2018; Szczegóła and Kwiatkowski 2017). On the other hand, the political response to these claims is hybrid, combining the rationalities of the welfare state and neoliberal capitalist policies. For example, the flagship welfare program of the Law and Justice Party [Prawo i Sprawiedliwość] governing Poland since 2015 , known as the 500+, offers a direct financial transfer to families with children (instead of tax reductions, school vouchers, etc.). The family is supposed to manage the money transferred by the state on its own. The amount they receive (approximately 116 Euros per month per child) reduces their consumption rather than stimulating individual entrepreneurship.

Social transfers were carried out during the whole period of Polish transformation, and they were not aimed at encouraging individuals to undertake business activities, but rather at pushing "dispensable" people out of the labor market, for example, through a system of the so-called bridging pensions (the possibility to retire before reaching the statutory age of retirement) (cf. Gomułka 2016:21). One of the recipients of social transfers has been, along with the lower classes and the former working-class, pauperized intelligentsia whose education and expertise are undervalued in the neoliberal labor market. In fact, the concept of the subjectificated individual, homo oeconomicus or "entrepreneur of the self" who plays a crucial role in the technology of neoliberal governmentality (Bröckling 2007; Foucault 2008:296), does not apply to a vast part of the population in the post-socialist state, raised in the economy of shortage or in the period of a turbulent shift into peripheral capitalism. Whereas the subject-figure of "entrepreneur of the self" is successfully applied in the studies on subjectification practices embedded in a direct transfer of Western neoliberal culture and the discourse of governing the Self (e.g., a study of coaching by Bogołębski 2014 or an analysis of the new patterns of parametrization implemented in Polish universities to measure the output of Polish scholars [Ostrowicka and Spychalska-Stasiak 2017]), in the Polish-specific genealogical analysis, this figure seems insufficient to conduct a proper reconstruction of local subject-making processes. I am far from defending a prejudiced concept of homo sovieticus as an allegedly typical identity for an Eastern European subject: economically unresourceful, but entitled and politically manipulable (cf. Sztompka 2001:22). Nonetheless, the shaping of a subject in the setting of a country catching up with the West is not only a governing-discursive process, but also a symbolic and emotional one, and this dimension seems unappreciated in the (post)Foucauldian perspective. In the case of Poland and other post-socialist 
societies, the more relevant model of a subject may be "a practitioner of the self," a type of individual who is subjectificated not within a given rationality of governing the population, but through their own practices of thoughtful/helpless responding to the conditions of economic and dignity shortages and of symbolic-cultural peripherality.

What fits into the Foucauldian thinking is that in Poland this hybrid and partially imitative form of governance produces a considerable margin of freedom in comparison to the socialist regime (cf. Foucault 2008:22), but primarily in legal or constitutional terms rather than in a microeconomic and socio-psychological perspective. Taking into account the expansive nature of neoliberal discourses in Poland, followed by discursive and non-discursive practices applied with or without "success" in the institutional and private domains, we may speak about post-socialist market governmentality characterized by a dispositif of modernization/ civilization security. The notions of governmentality and dispositif of security refer to Western European narratives and processes. In consequence, the modern change in the art of government in the Latin West, crucial for Foucault, in Eastern Europe, may have appeared as a violent shift rather than as the "natural" fruit of an endogenic metamorphosis of political and intellectual thought. Therefore, the incorporation of Foucault's concepts into the process of analyzing post-socialist democracies in Central and Eastern Europe should entail a cultural and political translation of this methodology. Otherwise, the use of the categories of governmentality, dispositif, or "entrepreneur of the self" in the post-socialist context should be revisited as an imitative rewriting of the Eastern European experience in accordance with Western narratives and critical theory.

\section{The German and the Polish Dispositif Case Studies-A Comparison}

To illustrate the contextual differences that leave an imprint on the analyses, I will refer to two case studies, one German and the other-Polish, which discuss education in terms of the Foucauldian dispositif. I have decided to focus on German and Polish research due to the fact that they are both similar and different. Most importantly, Foucault himself was interested in contemporary German governmentality and its social tools. Thus, German scholars who do research in this field may directly refer to his findings and thus continue his genealogical work. Polish scholars, by contrast, need to search for analogies and differences between Foucault's concept and local discourses and social practices. In other words, they need to test the Western genealogy and adapt it to the local context. At the same time, both German and Polish case studies that I examine below pose similar questions about the subject that is produced in the process of education-a fundamental social institution for governing people. Education is one of the key concepts of power/knowledge because its institutionally encompasses a social group (children and young adults) that consists of the most susceptible recipients of practices of the self (Ball 2017). The formation of the members of this group as economic and political subjects dictates the directions of society's development and is a subject of particular concern to those who create public policies.

In Norbert Ricken's works, education (Bildung in German) is conceptualized and operationalized as a dispositif due to its historical and diachronic constitution reflecting the post-enlightenment concept of a free and self-conscious subject that is guaranteed by modern relations of power (Ricken 2006:172ff). 
Education as a dispositif of security refers to a set of discourses, practices, and institutions which in modernity achieved the commonly accepted status of having no alternative and being irreplaceable in Western societies. This self-evidence and lack of alternatives constitute the power of education (Ricken 2015:41-42). Starting from the famous German philosophers and education theorists, such as Wilhelm von Humboldt and Immanuel Kant, Ricken focuses on the interplay between pedagogic discourses, institutions or practices, and the patterns of subjectification developed and implemented in Germany and other Western European societies in a particular historical moment: the fall of the tradition of the absolutist state belonging to a prince or a king, and a fiasco of the enlightenment and republican idea of the volonté générale. This led to the development of the idea of a negative state, refraining from direct interference with its citizens' lives, but focused on guaranteeing them safety. At the beginning of the $19^{\text {th }}$ century, education started being used as an instrument of general normalization of individuals, legitimized by the Kantian dictum saying that one becomes truly oneself only when, as a result of education, one gains self-awareness (Ricken 2015:44-45).

From this perspective, a dispositif of education should be regarded as an infra-social category which refers to a specific cultural pattern of interpretation concerning modern selves, their social roles, and fates. Ricken focuses on educational reforms introduced during the reign of the Prussian king Frederick William III and supported discursively by the thought of Kant and Humboldt. In his opinion, the educational changes of that period constitute the core of the social transformation which took place between 1780 and 1820 in Prussia and Western Europe, and which was connected to the shift towards non-disciplinary and pastoral rationality-in the post-enlightenment sense, stressing the self-education and self-disciplining of individuals, that is subjectivation happening within the frames of a specific form of governing the population. This is why Ricken believes education to be a pattern of interpretation that regulates not only the positive relationship between the individual and their own self, but also all social relations and orientation towards the common good (Ricken 2015:45-46).

Ricken asks whether the diagnosis that education functions as a dispositif of security is nowadays accurate (Ricken 2015:46-47). To this end, he confronts Foucault's perspective with, among others, Pierre Bourdieu and Jean-Claude Passeron's concepts of the reproduction of cultural capital through the schooling system. Ricken claims that the educational pattern of interpretation or dispositif, though changing in accordance with the demands of the epoch, in late modernity, loses its operating force and becomes a structure of the fading order of knowledge. Ricken does not reject the Foucauldian categories of governmentality and dispositif, but he points to their subordination to the functionality of a given social system. What becomes the real goal is not the formation of self-aware social subjects, but of individuals who fit in conventional social relations. Moreover, education can no longer be seen as a field of "ready-made" subjectifying practices; its impact on the self is possible only in a specific way or in connection to other areas of power/knowledge (Ricken 2015:51-55; 2019). To sum up, in Ricken's (2006:199ff) research, which is partially a genealogical reconstruction and partially prospective speculation, the dispositif plays the role of a category that is sensitive to the historical and political context, but one that can be functionalized (empirically and theoretically) as a strategic system of discourses, practices, and institutions that influence one another. 
In post-socialist Poland, Helena Ostrowicka (2012; 2015) conducted a post-Foucauldian dispositif analysis of the education of teenagers. For this author, governmentality is a general meta-category, which "is bound neither to a single type of rationality (a neoliberal one) nor to one single normativity" (Ostrowicka 2015:23 [trans. MNF]). Consequently, a dispositif is regarded as a social technology that is neither ideologically nor historically determined, but realizes the rationality of any governance. Under this premise, Ostrowicka carries out a dispositif analysis of a nexus of social power, discourse, and state policy, which conditions the desired (according to educational expertise) subjectivity of Polish teenagers. On the basis of post-Foucauldian discourse analysis and the textual corpus of research reports on Polish teenagers published in educational journals, as well as media discourse on a 14-yearold schoolgirl who committed suicide, Ostrowicka (2012:136 [trans. MNF]) distinguishes a dispositif of age, which "makes a link between young age and educational institutions, mainly school, through a space-time of technical possibilities of identification, control, and positioning of the learning subject." While discussing the dispositif of age, Ostrowicka (2015:177-178) focuses on interconnections between local knowledge about young people and the European Union's educational policy, as well as on the labor market in Poland and in the EU or social processes of normative change.

For Ostrowicka (2012:36ff; 2015:133ff), the basic theoretical reference is the Foucauldian model of the dispositif of security linked to neoliberal governmentality. In her research in the Polish post-socialist context, she, however, applies a technologically-oriented approach to studying the dispositif. In consequence, the educational dispositif of age functions as a hybrid device of the belated and im- itative modernization processes, whereas the neoliberal dimension of security serves as just one of the strategies (apart from juridical and disciplinary mechanisms of power) of playing a power game between the Center and Periphery. Ostrowicka does not explicitly problematize this local context, rather trying to universalize her category of the dispositif of age in relation to the system of education as such (at least in the context of the European Union). Still, the conclusions of her research provide an opportunity to ask questions about: 1) the local dynamics of the changes in conceptualizing young adults and students' status in the education discourse; 2) the mutual relations between Western and Polish discourses and educational practices towards young adults, and 3) the reality of Polish institutions and educational practices conforming to the discourse of the subjectivity of the youth copied from the West. Extrapolated from the field of education, the above-mentioned issues are equally relevant to other areas of post-Foucauldian analyses performed in the local, Eastern European context (e.g., studies of labor, citizenship, or the normalization of sexuality). Each of these cases is connected with the circulation of Western discursive practices and models of social practices. This process is not only conditioned by the local genealogy of power, but also the position of the examined portion of social reality in the network of dependencies between the ideological Center of Europe and its Peripheries.

\section{Conclusion: A Proposal for a "Post- Socialist" Dispositif Analysis}

The aim of this article is not to discourage anyone from using dispositif analysis in a post-socialist field of research, but to emphasize the necessity of methodological adjustment and supplementation of the post-Foucauldian perspective in order to minimize 
a mechanical imitation of the Western studies on neoliberal power in the Eastern European context. Therefore, I propose a few research guidelines for post-Foucauldian research conducted in post-socialist states such as Poland. Although in my analyses, I have focused on a comparison between German and Polish research, my final remarks are applicable to the post-Foucauldian approach to discourse and the dispositive as a whole. As in the case studies that I have discussed, what serves as a challenge for the dispositif analysis in the post-socialist context, is critical and self-reflective dissociation from the Western genealogy of power, at the same time, retaining the basic assumptions of the post-Foucauldian perspective on the strategic role of discourse and the dispositif in the contemporary art of government. Furthermore, the Foucauldian concepts that serve as analytical categories in the studies of post-socialist power relations need to be supplemented with the local designations whose critical descriptions can be empirically verified. Only then is it possible to use (post)Foucauldian tools to draw conclusions on the models of subjectivity that are typical of a given research field.

In the case of researching the Polish post-socialist art of government, the first step should cover enriched hermeneutic discourse analysis and the analysis of practices connected to it, with elements of macroeconomic, politological, and macro-sociological analysis of the objectivization of empirical reality. Foucault did not do this, concentrating on intellectual discourse. In his case, such a narrowing could pass muster because he analyzed the rationalities of government which emerged historically and evolutionally from the changes in the Western European state and economy, and were not imitative, technocratic, and, to a large extent, implemented in a revolutionary way on top of a collapsing socialist regime. The first step of a "post-socialist" dispositif analysis should be gathering macroeconomic and macrosocial indices referring not only to the gross domestic product or dynamics of economic growth, but also to social stratification and the level of income inequalities. Between 1980 and 2017 the latter in Polish society showed the fastest growth in Europe, according to the World Inequality Lab report (Blanchet, Chancel, and Gethin 2019), which points to the local domination of the neoliberal model of society characterized by market competition, alongside the negative results of this model. However, it is only the confrontation of the abovementioned indices with the indicators of civil liberties, the evaluation of democratic institutions, and the individual assessment of one's well-being and sense of social justice (e.g., Diagnoza Społeczna ${ }^{3}$ [Social Diagnosis], European Social Survey ${ }^{4}$ ) that allows one to place the dispositif of post-socialist market governmentality within the field of global and local socio-economic relationships.

For the same reason, dispositif analysis carried out in Poland should be sensitive to the modernizing and dignity functions of practices activated in dispositifs and referring to the tension between the Western Center and the Eastern Peripheries of Europe: both within the intersocietal framework, between economically developed and democratically stable societies and societies which are developing and aspiring to (an idealized) Western quality of democratic social life, and the intrasocietal framework, between those social classes that manage better in neoliberal capitalism and groups experiencing deprivation. At the intersection of these dimensions, one may distinguish the following types of practices of normalization typical in Central and Eastern European societies:

\footnotetext{
${ }^{3}$ See: http://www.diagnoza.com/. Retrieved January 03, 2021.

${ }^{4}$ See: http://www.europeansocialsurvey.org/. Retrieved January 03, 2021.
} 
Table 1. The practices of normalization in post-socialist societies with reference to the Center-Periphery relationship

\section{Modernizing function}

Modernizing and (anti)Westernizing practices:

Intersocietal

inequalities oriented towards economic, institutional, and axiological "catching up" with Western Europe or rejecting the idea of imitative change

\section{Dignity function}

Practices connected to dignity and settling accounts: oriented towards expecting moral and symbolic reparations from the West for historically determining the international position of a postsocialist state

Dignity and class practices:

Modernizing and class practices:

Intrasocietal oriented towards drawing even with the West inequalities materially by observing the lifestyles of local elites oriented towards problematizing the unfair separation of material goods and symbolic positions within a society

Source: Self-elaboration.

Identifying these practices would help define the kind of situation of social crisis that the dispositif of Polish art of government de facto answers to: to what extent it is a derivative of a neoliberal political economy, and to what extent-a reaction to social resentments connected to the geopolitical hierarchy of collective entities. Consequently, the category of the dispositif should be conceptualized as a discursive-non-discursive ensemble that is responsive to fluctuations of governing strategies, where the neoliberal component is involved in a game of power with other types of logic of governing people. The analysis of the Center-Peripheric distribution of economic, social, and cultural capital is useful in this context. Still, frequent attempts at linking Foucault's perspective directly with Pierre Bourdieu's theory would not work within the context of Eastern Europe. As in the case of Foucault, they could be seen as a quasi-colonial transfer of theories (Bourdieu did not do research on Poland or other post-socialist countries, either). However, there are a few Polish researchers, for example, Tomasz Warczok and Tomasz Zarycki (2014) and Agata Zysiak (2019), who promote peripheral uses of Bourdieu's theory, adjusted to the regional fields of power relations.

Moreover, what should be taken into account in this context is the imitative dimension of discourse and non-discursive practices involved in the post-socialist dispositif. Discourse on subjectivation can rather easily be copied from the West, but the discursive imitation does not have to involve the implementation of practices that operate according to given governmentality and fulfill promises made in the westernized discourse (or this implementation is but apparent and the final subjectivation becomes also virtual). In order to minimize the influence of textual idealism on research results, the researcher should focus, on the one hand, on the symbolic function of discourse, institutions, and their practices, and on the other, on individual and collective techniques of facing the peripheral reality. 
The abovementioned phase of the analysis should include the reconstruction of post-socialist modes of subjectification. The proposed category of "a practitioner of the self" can serve not only as a kind of umbrella term to gather various types of practices of post-socialist normalization with regard to particular biographic strategies of individuals, but it can be used as well with an aim to distinguish both 1) semiotic messages embedded in the ways of positioning the self towards others (other social classes and groups, as well as other societies, especially Western Europeans) and 2) everyday practices of producing, confirming, or resisting a particular type of local subjectivity.

The first task will be facilitated by introducing to one's research selected aspects of semiology dealing with the mythmaking function of the linguistic level of discourse, which aims at normalizing the social order (Barthes 1972; in the Polish context, Wasilewski 2012; Napiórkowski 2018). The second one requires opening up to the methods of an anthropology of the contemporary, aimed at researching cultural practices of contemporary individuals and social groups within their "natural," everyday environment in the context of current relationships between politics, scientific knowledge, and economy (Sulima 2000; Łuczeczko 2006; Rabinow and Stavri-

\section{References}

Ahmad, Aijaz. 1992. In Theory. London: Verso.

Angermüller, Johannes. 2010. “Widerspenstiger Sinn. Skizze eines diskursanalytischen Forschungsprogramms nach dem Strukturalismus [Unruly Sense. Sketch of a Discourse-Analytical Research Program after Structuralism]." Pp. 71-100 in Diskursanalyse meets Gouvernementalitätsforschung. Perspektiven auf das Verhältnis von Subjekt, Sprache, Macht und Wissen [Discourse anakis 2013). Finally, the confrontation of the subject model described by Foucault and elaborated on by his Western European commentators with forms of subjectivity developing within Polish rationalities of government would require asking the question about the local discursive and cultural identity. Here, what is helpful is cultural identity analysis, carried out at the intersection of philosophy and psychology, and developed in Poland, inter alia, by Andrzej Leder (2014) and Piotr Augustyniak (2015; 2019). Despite the fact that Foucault is not the main reference point for these authors, their research fits into the spectrum of poststructuralism, and their goal to contribute to the academic reflection on the cultural and discursive construction of individual existence by introducing the general thesis of "power coming from everywhere."

The post-Foucauldian perspective has already taken an immense step beyond Foucault's thought. Eastern European scholars may take another step forward and, to paraphrase Dipesh Chakrabarty, bring this analytics of power to a provincial level so that it could render the specificity of Eastern Europe in an equal dialogue with Western critical theory and prove that the dispositif does not constitute a "fancy" category borrowed from the West, but it regulates the crisis and normalizes the post-socialist society.

Analysis Meets Governmentality Research. Perspectives on the Relationship between Subject, Language, Power, and Knowledge], edited by J. Angermüller and S. van Dyk. Frankfurt am Main, New York: Campus.

Angermüller, Johannes and Silke van Dyk, eds. 2010. Diskursanalyse meets Gouvermentalitätsforschung. Perspektiven auf das Verhältnis von Subjekt, Sprache, Macht und Wissen [Discourse 
Analysis Meets Governmentality Research. Perspectives on the Relationship between Subject, Language, Power, and Knowledge]. Frankfurt am Main, New York: Campus.

Augustyniak, Piotr. 2015. Homo polacus: Eseje o polskiej duszy [Homo Polacus: Essays on the Polish Soul]. Cracow: Znak.

Augustyniak, Piotr. 2019. Wyspiański: Burzenie polskiego kościoła. Studium o "Wyzwoleniu" [Wyspiański: Demolishing the Polish Church. A Study of "Liberation"]. Cracow: Znak.

Ball, Stephen J. 2017. Foucault as Educator. Wiesbaden: Springer VS.

Barthes, Roland. 1972. Mythologies. New York: Hill and Wang.

Becker, Gary S., François Ewald, and Bernard E. Harcourt. 2012. “'Becker on Ewald on Foucault on Becker': American Neoliberalism and Michel Foucault's 1979 'Birth of Biopolitics' Lectures." University of Chicago Institute for Law E Economics Olin Research Paper No. 614; U of Chicago, Public Law Working Paper No. 401. Retrieved January 03, 2021 (http://dx.doi.org/10.2139/ ssrn.2142163).

Behrent, Michael C. 2009. “Liberalism without Humanism: Michel Foucault and the Free Market Creed 1976-1979." Modern Intellectual History 6(3):539-568.

Behrent, Michael C. 2016. "Conclusion: The Strange Failure (and Peculiar Success) of Foucault's Project." Pp. 176-186 in Foucault and Neoliberalism, edited by. D. Zamora and M. C. Behrent. Cambridge: Polity Press.

Bielska, Beata and Michał Wróblewski. 2017. "Central-Eastern Europe as Postcolonially Involved (Sub)Peripheries." Eastern European Countryside 23:209-220.

Blanchet, Thomas, Lucas Chancel, and Amory Gethin. 2019. "How Unequal Is Europe? Evidence from Distributional National Accounts, 1980-2017." WID.world WORKING PAPER No. 2019/06. Retrieved June 14, 2019 (https://wid.world/document/ bcg2019-full-paper/).

Bogołębski, Tomasz. 2014. “Coaching w optyce rządomyślności. Próba krytycznej analizy zjawiska [Coaching in the Context of Governmentality. An Attempt at a Critical Analysis]." Pp.173-196 in Dyskurs elit symbolicznych. Próba diagnozy [Discourse of Symbolic Elites. An Attempt at a Diagnosis], edited by M. Czyżewski et al. Warsaw: Sedno.

Bosančić, Saša. 2018. “Die Forschungsperspektive der Interpretativen Subjektivierungsanalyse [The Research Perspective of the Interpretative Subjectification Analysis]." Pp. 43-64 in Subjekt und Subjektivierung, Empirische und theoretische Perspektiven auf Subjektivierungsprozesse [Subject and Subjectification, Empirical and Theoretical Perspectives on Subjectification Processes], edited by A. Geimer, S. Amlingand, and S. Bosančić. Wiesbaden: Springer VS.

Bosančić, Saša and Reiner Keller, eds. 2016. Perspektiven wissenssoziologischer Diskursforschung [Perspectives of the Sociology of Knowledge on Discourse Research]. Wiesbaden: Springer VS.

Bosančić Saša, Lisa Pfahl, and Boris Traue. 2019. “Empirische Subjektivierungsanalyse: Entwicklung des Forschungsfeldes und methodische Maximen der Subjektivierungsforschung [Empirical Analysis of Subjectification: Development of the Research Field and Methodological Maxims of Subjectification Research]." Pp. 135-150 in Diskursive Konstruktionen, Theorie und Praxis der Diskursforschung [Discursive Constructions, Theory, and Practice of Discourse Research], edited by S. Bosančić and R. Keller. Wiesbaden: Springer VS.

Brown, Wendy. 2015. Undoing the Demos: Neoliberalism's Stealth Revolution. New York: Zone Books.

Bröckling, Ulrich. 2007. Das unternehmerische Selbst. Soziologie einer Subjektivierungsform [The Entrepreneurial Self. Sociology of a Form of Subjectivation]. Frankfurt am Main: Suhrkamp.

Bröckling, Ulrich, Susanne Krasmann, and Thomas Lemke, eds. 2010. Governmentality: Current Issues and Future Challenges. New York: Routledge.

Bührmann, Andrea D. 2005. “Das Auftauchen des unternehmerischen Selbst und seine gegenwärtige Hegemonialität. Einige grundlegende Anmerkungen zur Analyse des (Trans-) Formierungsgeschehens moderner Subjektivierungsweisen [The Emerging of the Entrepreneurial Self and Its Current Hegemony. Some Basic Reflections on How to Analyze the Formation and Transformation of Modern Forms of Subjectivity]." Forum Qualitative Sozialforschung / Forum: Qualitative Social Research 6(1): Art. 1. Retrieved August 07, 2019 (http://nbn-resolving.de/urn:nbn:de:0114-fqs0501165).

Bührmann, Andrea D. and Werner Schneider. 2008. Vom Diskurs zum Dispositiv: Eine Einführung in die Dispositivanalyse [From Discourse to Dispositive: An Introduction to Dispositive Analysis]. Bielefeld: Transcript.

Caborn, Joannah. 2007. "On the Methodology of Dispositive Analyses." Critical Approaches to Discourse Analysis Across Disciplines 1:112-123. 
Chutorański, Maksymilian. 2013a. "Krajowe Ramy Wysokiego Performansu? [The National Framework for High Performance]." Studia Pedagogiczne 66:63-76.

Chutorański, Maksymilian. 2013b. “Urządzanie uniwersytetu [The Governmentality of the University]." Pp. 57-78 in Fabryki dyplomów czy universitas? [Diploma Mills or Universitas?], edited by M. Czerepaniak-Walczak. Cracow: Impuls.

Czyżewski, Marek. 2012. “Wiedza specjalistyczna i praktyka społeczna - przemiany i pułapki [Specialist Knowledge and Social Practice-Traps and Transformations]." Pp. 71-93 in Kontrowersje dyskursywne. Między wiedza specjalistyczna a praktyka społeczna [Discursive Controversies. Between Specialist Knowledge and Social Practice], edited by A. Jabłoński, J. Szymczyk, and M. Zemło. Lublin: Wydawnictwo KUL.

Dean, Mitchell. 2018. "Foucault and the Neoliberalism Controversy." Pp. 40-53 in The SAGE Handbook of Neoliberalism, edited by D. Cahill et al. London: SAGE Publications.

Dean, Mitchell and Daniel Zamora. 2018. "Did Foucault Reinvent His History of Sexuality through the Prism of Neoliberalism?" Los Angeles Review of Books, 18 ${ }^{\text {th }}$ April. Retrieved December 28, 2018 (https:// www.lareviewofbooks.org/article/did-foucault-reinvent-his-history-of-sexuality-through-the-prism-of-neoliberalism/).

Diaz-Bone, Rainer and Ronald Hartz, eds. 2017. Dispositiv und Ökonomie. Diskurs- und dispositiv analytische Perspektiven auf Märkte und Organisationen [Dispositive and Economy. Discourse and Dispositive Analytical Perspectives on Markets and Organizations]. Wiesbaden: Springer VS.

Diaz-Bone, Rainer et al. 2007. "The Field of Foucauldian Discourse Analysis: Structures, Developments and Perspectives." Forum Qualitative Sozialforschung / Forum: Qualitative Social Research 8(2): Art. 30. Retrieved August 07, 2019 (http://nbn-resolving.de/urn:nbn:de:0114-fqs0702305).

Elden, Stuart. 2016a. Foucault's Last Decade: An Interviewwith Stuart Elden. Critical Theory. Retrieved December 27, 2018 (http://www.critical-theory.com/foucaults-last-decade-an-interview-with-stuart-elden/).

Elden, Stuart. 2016b. Foucault's Last Decade. Cambridge: Polity Press.

Eribon, Didier. 1991. Michel Foucault. Cambridge: Harvard University Press.

Fisch, Michael. 2011. Werke und Freuden. Michel Foucault - eine Biographie [Works and Joys. Michel Foucault-A Biography]. Bielefeld: Transcript.
Foucault, Michel. 1976. Discipline and Punish: The Birth of the Prison. London: Penguin.

Foucault, Michel. 1980. "The Confession of the Flesh." Pp. 194228 in Power/Knowledge: Selected Interviews \& Other Writings 1972-1977 by Michel Foucault, edited by C. Gordon. New York: Pantheon Books.

Foucault, Michel. 1981. “The Order of Discourse.” Pp. 51-78 in Untying the Text: A Post-Structuralist Reader, edited by R. Young. Boston, London, Henley: Routledge \& Kegan Paul.

Foucault, Michel. 1991. "Politics and Ethics: An Interview." Pp. 373-380 in The Foucault Reader, edited by P. Rabinow. New York: Pantheon.

Foucault, Michel. 2001a. "Question à Michel Foucault sur la géographie [Question to Michel Foucault on Geography]." Pp. 28-40 in M. Foucault, Dits et écrits II. 1976-1988 [Words and Writings II. 1976-1988]. Paris: Gallimard.

Foucault, Michel. 2001b. "Michel Foucault: crimes et châtiments en U.R.S.S. et ailleurs... [Michel Foucault: Crimes and Punishments in USSR and Elsewhere...]." Pp. 63-74 in M. Foucault, Dits et écrits II. 1976-1988 [Words and Writings II. 19761988]. Paris: Gallimard.

Foucault, Michel. 2001c. "Pouvoir et savoir [Power and Knowledge]." Pp. 399-414 in M. Foucault, Dits et écrits II. 1976-1988 [Words and Writings II. 1976-1988]. Paris: Gallimard.

Foucault, Michel. 2001d. “Michel Foucault: «Il n'y a pas de neutralité possible» [Michel Foucault: 'No Neutrality Is Possible']." Pp. 1157-1159 in M. Foucault, Dits et écrits II. 1976-1988 [Words and Writings II. 1976-1988]. Paris: Gallimard.

Foucault, Michel. 2001e. “Foucault étudie la raison d'État [Foucault Studies Political Reason]." Pp. 801-805 in M. Foucault, Dits et écrits II. 1976-1988 [Words and Writings II. 1976-1988]. Paris: Gallimard.

Foucault, Michel. 2001f. "Le premier pas de la colonisation de l'Occident [The First Step in the Colonization of the West]." Pp. 1080-1088 in M. Foucault, Dits et écrits II. 1976-1988 [Words and Writings II. 1976-1988]. Paris: Gallimard.

Foucault, Michel. 2003. Society Must Be Defended. London: Allen Lane.

Foucault, Michel. 2006. History of Madness. New York: Routledge. 
Foucault, Michel. 2007. Security, Territory, Population: Lectures at the Collège de France 1977-1978. London: Palgrave Macmillan.

Foucault, Michel. 2008. The Birth of Biopolitics: Lectures at the Collège de France 1978-1979. London: Palgrave.

Foucault, Michel and Paul Rabinow. 1984. "Polemics, Politics, and Problematizations: An Interview with Michel Foucault." Pp. 381-390 in The Foucault Reader, edited by P. Rabinow. New York: Pantheon.

Gdula, Maciej. 2018. Nowy autorytaryzm [New Authoritarianism]. Warsaw: Wydawnictwo Krytyki Politycznej.

Gomułka, Stanisław. 2016. "Poland's Economic and Social Transformation 1989-2014 and Contemporary Challenges." Central Bank Review 16(1):19-23.

Hamann, Julian et al. 2019. "The Academic Dispositif: Towards a Context-Centred Discourse Analysis." Quantifying Approaches to Discourse for Social Scientists, Postdisciplinary Studies in Discourse, edited by R. Scholz. Retrieved January 03, 2021 (https:// doi.org/10.1007/978-3-319-97370-8_3).

Hansen, Magnus Paulsen. 2015. “Foucault's Flirt? Neoliberalism, the Left and the Welfare State: A Commentary on La dernière leçon de Michel Foucault and Critiquer Foucault." Foucault Studies 20:291-306.

Hoffarth, Britta. 2013. “Schmutzige Witze. Erkundung eines Bildungsereignisses im Geschlechter-Dispositiv [Dirty Jokes. Exploration of an Educational Event in the Gender Dispositive]." Pp. 91-110 in Verortungen des Dispositiv-Begriffs. Analytische Einsätze zu Raum, Bildung, Politik [Locations of the Dispositive Concept. Analytical Assignments to Space, Education, Politics], edited by J. Caborn Wengler, B. Hoffarth, and Ł. Kumięga. Wiesbaden: Springer VS.

Hugo-Bader, Jacek. 2016. Skucha [Remorse]. Warsaw: Agora.

Jäger, Siegfried. 2001. “Discourse and Knowledge: Theoretical and Methodological Aspects of a Critical Discourse and Dispositive Analysis." Pp. 32-62 in Methods of Critical Discourse Analysis, edited by R. Wodak and M. Meyer. London: Sage.

Jeanpierre, Laurent. 2006. “Une sociologie foucaldienne du néolibéralisme est-elle possible? [Is Foucauldian Sociology of Neoliberalism Possible?]." Sociologie et sociétés 38(2):87-111.

Keller, Rainer. 2011. Wissenssoziologische Diskursanalyse: Grundlegung eines Forschungsprogramms [The Sociology of Knowledge
Discourse Analysis: Laying the Foundations for a Research Program]. Wiesbaden: VS-Verlag.

Keller, Rainer, Werner Schneider, and Willy Viehöver, eds. 2012. Diskurs-Macht-Subjekt: Theorie und Empirie von Subjektivierung in der Diskursforschung [Discourse-Power-Subject: Theory and Empiricism of Subjectification in Discourse Research]. Wiesbaden: VS.

Kovacs, János Mátyás. 1992. Reform and Transformation: Eastern European Economics on the Threshold of Change. London: Routledge.

Kubala, Konrad. 2019. Racjonalność w dyskursach o pracy w Polsce (po)transformacyjnej [Rationality in Discourses about Work in (Post) Transformation Poland]. Lodz: Wydawnictwo Uniwersytetu Łódzkiego.

Laczó, Ferenc and Joanna Wawrzyniak. 2017. "Memories of 1989 in Europe: Between Hope, Dismay, and Neglect." East European Politics, Societies and Cultures 31(3):431-438.

Lagasnerie, Geoffroy de. 2012. La dernière leçon de Michel Foucault [The Last Lesson from Michel Foucault]. Paris: Fayard.

Larner, Wendy. 2000. "Neoliberalism: Policy, Ideology, Governmentality." Studies in Political Economy 63:5-25.

Laval, Christian. 2018. Foucault, Bourdieu et la question néolibérale [Foucault, Bourdieu and the Neoliberal Question]. Paris: Éditions La Découverte.

Leder, Andrzej. 2014. Prześniona rewolucja: Ćwiczenia z logiki historycznej [Sleepwalking through a Revolution. Exercises in Historical Logic]. Warsaw: Wydawnictwo Krytyki Politycznej.

Lemke, Thomas. 2001. "The Birth of Bio-Politics-Michel Foucault's Lecture at the Collège de France on Neo-Liberal Governmentality." Economy \& Society 30(2):190-207.

Lewicki, Mikołaj. 2018. Przyszłość nie może się zaczać: Polski dyskurs transformacyjny w perspektywie teorii modernizacji i teorii czasu [The Future Cannot Begin: Polish Transformation Discourse in the Context of the Modernization Theory and Time Theory]. Warsaw: Scholar.

Link, Jürgen. 2006. “Dispositiv und Interdiskurs. Mit Überlegungen zum Dreieck Foucault - Bourdieu - Luhmann [Dispositive and Interdiscourse. With Reflections on the FoucaultBourdieu-Luhmann Triangle]." Pp. 219-238 in Foucault in den Kulturwissenschaften. Eine Bestandsaufnahme [Foucault in Cultural 
Studies. An Inventory], edited by C. Kammler and R. Parr. Heidelberg: Synchron.

Łuczeczko, Paweł. 2006. Zrozumieć własna kulturę: Antropologia współczesności w Polsce [Understanding One's Culture: Anthropology of Modern Times in Poland]. Cracow: Nomos.

Macey, David. 1993. The Lives of Michel Foucault. New York: Vintage.

Miller, James. 1993. The Passion of Michel Foucault. New York: HarperCollins.

Mikołajewska-Zając, Karolina and Joanna Wawrzyniak. 2016. “Nostalgia jako narzędzie krytyki transformacji: Mit dobrego właściciela w opowieściach pracowników fabrycznych [Nostalgia as a Tool for Criticizing the Transformation: The Myth of a Good Owner in the Stories of Factory Workers]." Przeglad Socjologii Jakościowej 12(2):36-54.

Moore, David Choni. 2001. "Is the Post- in Postcolonial the Post- in Post-Soviet? Toward a Global Postcolonial Critique." PLMA 116(1):111-128.

Napiórkowski, Marcin. 2018. Mitologia współczesności [Contemporary Mythology]. Warsaw: PWN.

Nichols, Robert. 2010. "Postcolonial Studies and the Discourse of Foucault: Survey of a Field of Problematization." Foucault Studies 9:111-144.

Nowicka-Franczak, Magdalena. 2017. Niechciana debata. Spór o ksiażki Jana Tomasza Grossa [An Unwanted Debate. The Dispute over Jan Tomasz Gross's Books]. Warsaw: Sedno.

Ostrowicka, Helena. 2012. Urzadzanie młodzieży: Studium analityczno-krytyczne [Governmentalizing the Youth: A Critical Analytical Study]. Cracow: Impuls.

Ostrowicka, Helena. 2015. Przemyśleć z Michelem Foucaultem edukacyjne dyskursy o młodzieży: Dyspozytyw i urzadzanie [Rethinking Educational Discourses about the Youth with Michel Foucault: The Dispositif and Governmentality]. Cracow: Impuls.

Ostrowicka, Helena and Justyna Spychalska-Stasiak. 2017. “'Uodpowiedzialnianie' akademii - formacje wiedzy i władza parametryzacji w dyskursie akademickim ['Responsibilitizing' Academia-Knowledge Formations and the Power of Parametrization in Academic Discourse]." Nauka i Szkolnictwo Wyższe 49(1):105-131.

Paulus, Stefan. 2015. "Methodologische Überlegungen und methodisches Vorgehen bei einer intersektionalen Dispositivanalyse
[Methodological Considerations and Methodological Approach in an Intersectional Dispositive Analysis]." Forum Qualitative Sozialforschung / Forum: Qualitative Social Research 16(1): Art. 21. Retrieved August 07, 2019 (http://nbn-resolving.de/urn:nbn:de:0114-fqs1501210).

Pfahl, Lisa, Lena Schürmann, and Boris Traue. 2015. “Das Fleisch der Diskurse. Zur Verbindung von Biographie- und Diskursforschung in der wissenssoziologischen Subjektivierungsanalyse am Beispiel der Behindertenpädagogik [The Flesh of the Discourse. On the Connection of Biography and Discourse Research in the Sociology of Knowledge Analysis of Subjectivation Using the Example of the Education of People with Disabilities]." Pp. 89-106 in Erziehungswissenschaftliche Diskursforschung. Empirische Analysen zu Bildungs- und Erziehungsverhältnissen [Educational Discourse Research. Empirical Analyzes of Educational and Upbringing Relationships], edited by S. Fegter et al. Wiesbaden: Springer VS.

Porter-Szücs, Brian. 2014. Poland in the Modern World: Beyond Martyrdom. Chichester: Wiley.

Rabinow, Paul and Anthony Stavrianakis. 2013. Demands of the Day: On the Logic of Anthropological Inquiry. Chicago: University of Chicago Press.

Raffnsøe, Sverre, Marius Gudmand-Høyer, and Morten S. Thaning. 2016. "Foucault's Dispositive: The Perspicacity of Dispositive Analytics in Organizational Research." Organization 23(2):272-298.

Rehmann, Jan. 2016. "The Unfulfilled Promises of the Late Foucault and Foucauldian Governmentality Studies." Pp. 134-158 in Foucault and Neoliberalism, edited by D. Zamora and M. C. Behrent. Cambridge: Polity Press.

Ricken, Norbert. 2006. Die Ordnung der Bildung: Beiträge zu einer Genealogie der Bildung [Order of Education: Contributions to a Genealogy of Education]. Wiesbaden: VS Verlag.

Ricken, Norbert. 2015. “Bildung als Dispositiv: Bemerkungen zur (Macht-)Logik eines Subjektivierungsmusters [Education as a Dispositive: Comments on the (Power-) Logic of a Subjectification Pattern]." Pp. 41-58 in Medien - Bildung - Dispositive: Beiträge zu einer interdisziplinären Medienbildungsforschung [Media-Education-Dispositive: Contributions to Interdisciplinary Media Education Research], edited by J. Othmer and A. Weich. Wiesbaden: Springer VS.

Ricken, Norbert. 2019. “Bildung und Subjektivierung: Bemerkungen zum Verhältniszweier Theorieperspektiven [Education and Subjectification: Remarks on the Relationship between Two Theoretical Perspectives]." Pp. 95-118 in Subjektivierung: Erziehungswissenschaftliche Perspektiven [Subjectifica- 
tion: Educational Perspectives], edited by N. Ricken, R. Casale, and Ch. Thompson. Weinheim: Beltz Juventa Verlag.

Ryziński, Remigiusz. 2017. Foucault w Warszawie [Foucault in Warsaw]. Warsaw: Wydawnictwo Dowody na Istnienie.

Said, Edward W. 1983. The World, the Text, and the Critic. Cambridge, MA: Harvard University Press.

Sarasin, Philipp. 2005. Michel Foucault zur Einführung [Michel Foucault as an Introduction]. Hamburg: Junius Verlag.

Schneider, Werner. 2015. "Dispositive überall und nirgendwo? Anmerkungen zur Theorie und methodischen Praxis der Dispositivforschung [Dispositive Everywhere and Nowhere? Comments on the Theory and Methodological Practice of Dispositive Research]." Pp. 21-40 in Medien-Bildung-Dispositive: Beiträge zu einer interdisziplinären Medienbildungsforschung [Media-Education-Dispositive: Contributions to Interdisciplinary Media Education Research], edited by J. Othmer and A. Weich. Wiesbaden: Springer VS.

Sowa, Jan. 2015. Inna Rzeczpospolita jest możliwa! Widma przeszłości, wizje przyszłości [A Different Republic Is Possible! Spectres of the Past and Visions of the Future]. Warsaw: W.A.B.

Specter, Matthew. 2015. "Introduction." History and Theory: Forum: Foucault and Neoliberalism 54:367-371.

Spivak, Gayatri. 1988. “Can the Subaltern Speak?” Pp. 271-313 in Marxism and the Interpretation of Culture, edited by C. Nelson and L. Grossberg. Chicago: University of Illinois Press.

Sulima, Roch. 2000. Antropologia codzienności [An Anthropology of Commonplace]. Cracow: Wydawnictwo Uniwersytetu Jagiellońskiego.

Szczegóła, Lech and Mariusz Kwiatkowski. 2017. “Alternacja systemowa. Dobra zmiana w perspektywie socjologii sfery publicznej ["Systemic Alternation. The Good Change Viewed from the Perspective of the Sociology the Public Sphere]." Studia Socjologiczne 227(4):49-71.

Sztompka, Piotr. 2001. The Ambivalence of Social Change: Triumph or Trauma? Berlin: Wissenschaftszentrum Berlin für Sozialforschung GmbH.
Tuider, Elisabeth. 2007. "Diskursanalyse und Biographieforschung. Zum Wie und Warum von Subjektpositionierungen [Discourse Analysis and Biographical Research. On the How and Why of Subject Positioning]." Forum Qualitative Sozialforschung / Forum: Qualitative Social Research 8(2): Art. 6. Retrieved: September 07, 2019 (http://nbn-resolving.de/urn:nbn:de:0114-fqs070268).

Veyne, Paul. 2010. Foucault: His Thought, His Character. Cambridge: Polity Press.

Warczok, Tomasz and Tomasz Zarycki. 2014. “Bourdieu Recontextualized: Redefinitions of Western Critical Thought in the Periphery."Current Sociology 62(3):334-351.

Warczok, Tomasz and Tomasz Zarycki. 2016. Gra peryferyjna: Polska politologia w globalnym polu nauk społecznych [A Peripheral Game: Polish Political Science and Its Place in Global Social Sciences]. Warsaw: Scholar.

Wasilewski, Jacek. 2012. Opowieści o Polsce: Retoryka narracji [Stories about Poland. The Rhetoric of Narration]. Warsaw: Headmade.

Zamora, Daniel. 2014. "Can We Criticize Foucault?" Jacobin Magazine 12. Retrieved August 12, 2019 (https://www.jacobinmag.com/2014/12/foucault-interview/).

Zamora, Daniel and Michael C. Behrent, eds. 2016. Foucault and Neoliberalism. Cambridge: Polity Press.

Zarycki, Tomasz. 2014. Ideologies of Eastness in Central and Eastern Europe. London, New York: Routledge.

Zawieyski, Jerzy. 2011. Dzienniki. Tom I: Wybór z lat 1955-1959 [Journals. Volume 1: Selected Writings, 1955-1959]. Warsaw: Ośrodek Karta.

Ziółkowski, Marek. 2015. Teoria socjologiczna a transformacja społeczeństwa polskiego [Sociological Theory and the Transformation of the Polish Society]. Warsaw: Scholar.

Zysiak, Agata. 2019. "Hysteresis, Academic Biography, and Political Field in the People's Republic of Poland." Theory and Society 48(3):483-508.

\section{Citation}

Nowicka-Franczak, Magdalena. 2021. "Post-Foucauldian Discourse and Dispositif Analysis in the Post-Socialist Field of Research: Methodological Remarks." Qualitative Sociology Review 17(1):72-95. Retrieved Month, Year (http://www.qualitativesociologyreview.org/ENG/archive_eng.php). DOI: http://dx.doi.org/10.18778/1733-8077.17.1.6 